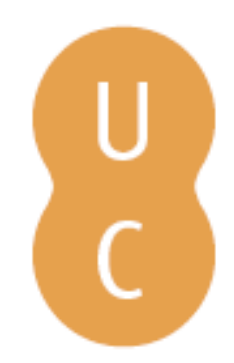

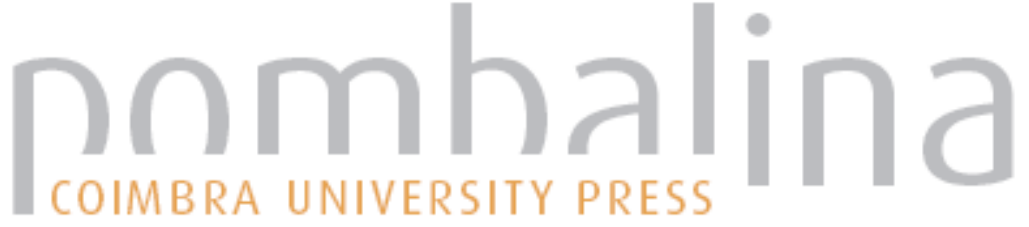

\section{Accrual-based accounting within the Malagasy urban municipalities}

Autor(es): $\quad$ Oliarilanto, Rakoto

Publicado por: Imprensa da Universidade de Coimbra

URL

persistente:

URI:http://hdl.handle.net/10316.2/32173

DOI:

DOl:http://dx.doi.org/10.14195/978-989-26-0422-0_8

Accessed : $\quad$ 26-Apr-2023 12:29:24

A navegação consulta e descarregamento dos títulos inseridos nas Bibliotecas Digitais UC Digitalis, UC Pombalina e UC Impactum, pressupõem a aceitação plena e sem reservas dos Termos e Condições de Uso destas Bibliotecas Digitais, disponíveis em https://digitalis.uc.pt/pt-pt/termos.

Conforme exposto nos referidos Termos e Condições de Uso, o descarregamento de títulos de acesso restrito requer uma licença válida de autorização devendo o utilizador aceder ao(s) documento(s) a partir de um endereço de IP da instituição detentora da supramencionada licença.

Ao utilizador é apenas permitido o descarregamento para uso pessoal, pelo que o emprego do(s) título(s) descarregado(s) para outro fim, designadamente comercial, carece de autorização do respetivo autor ou editor da obra.

Na medida em que todas as obras da UC Digitalis se encontram protegidas pelo Código do Direito de Autor e Direitos Conexos e demais legislação aplicável, toda a cópia, parcial ou total, deste documento, nos casos em que é legalmente admitida, deverá conter ou fazer-se acompanhar por este aviso. 


\section{Implementing Reforms in Public Sector Accounting}

Susana Jarge

Editor

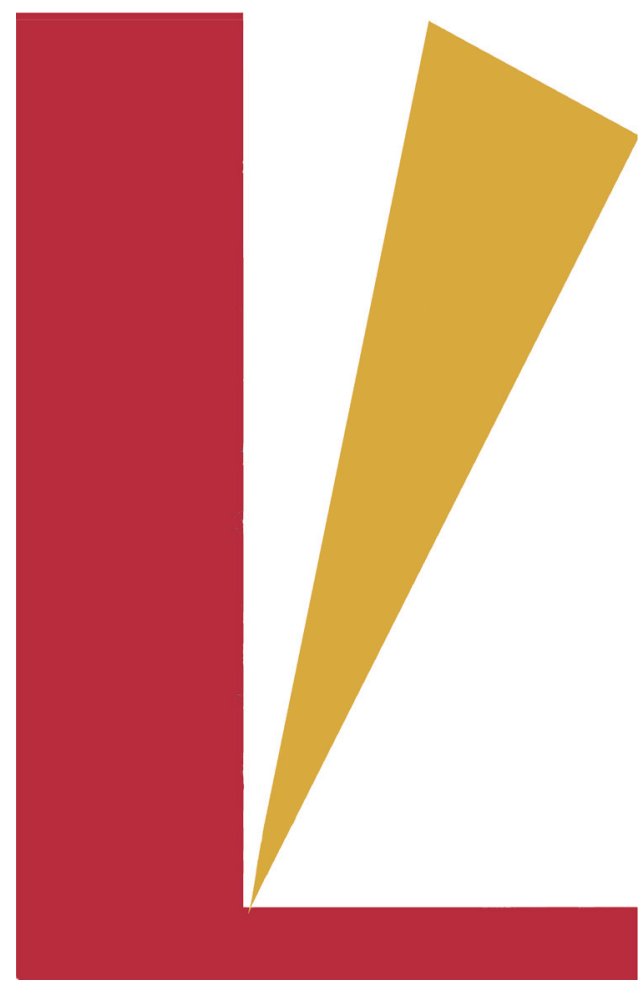


(Página deixada propositadamente em branco) 


\section{Implementing comparative Interational Reforms Governmental in Public Sector Accounting Accounting}

Susana Jorge Editor 
COORDENAÇÃO EDITORIAL

Imprensa da Universidade de Coimbra

Email: imprensauc@ci.uc.pt

URL: http://www.uc.pt/imprensa_uc

CONCEPÇÃO GRÁFICA

António Barros

\section{PAGINAÇÃO}

Simões \& Linhares, Lda.

\section{EXECUÇÃO GRÁFICA}

Simôes \& Linhares, Lda.

ISBN

978-989-8074-39-3

DEPÓSITO LEGAL

$281657 / 08$

\section{OBRA PUBLICADA COM O APOIO DE:}
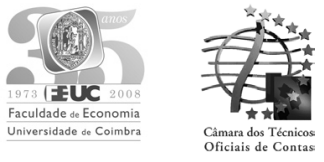

(C) Agosto 2008, IMPRENSA DA UNIVERSIDADE DE COIMBRA 
Rakoto Oliarilanto

\section{ACCRUAL-BASED ACCOUNTING WITHIN THE MALAGASY URBAN MUNICIPALITIES}

\section{Introduction}

Accrual accounting in the public sector has attracted significant interest of researchers in the past decade. It emerged from the idea that one of the ways leading to rationale public management is the adoption of the private sector management model (Pallot, 2001; Ezzamel et al., 2004, 2005; Wynne, 2005). Then, the accrual based accounting becomes more accepted within public entities and cash based models become more disused (Lande, 2006; Wynne, 2005).

Before the emergence of the accrual based model, the criterion of a good public management was the budgetary conformity. According to this formula, the cash receipts and the cash disbursements were the main basis of evaluation. The cash information - cash accounting and cash budgeting - were an important reference in monitoring financial decisions.

Since 1990, the situation has changed: in order to evaluate the costs of public goods and services, to evaluate political managers' performance, to reduce corruption or to prevent crises, the users required more transparent and more pertinent financial information as assets, liabilities, net profit and depreciation. This is, for example, the case of New Zealand government. In other respects, some governments such as France, Spain or the United Kingdom are motivated to engage an accounting change in order to give an image of modernisation (Lande, 2006). Other governments, such as Egypt, Algeria (Merrouche et al., 2005; Ouda, 2006) or Madagascar are compelled to change the accounting practice in order to assure the credibility towards the international donors. This paper is organized in five sections. The next section exposes the difficulties of this study, the second section lays out Lüder's contingency model, the third section shows the methodology and the fourth section discusses the study findings. The conclusion of this study is presented in the last section. 


\section{Distortion between normative referential and accounting practice}

Accrual accounting was instituted gradually from the year 2000 onwards. The first accounting reform took place in 2000. At the end of this reform, the Chart of Accounts for Government Operations 2000 (PCOP 2000) was elaborated and the moderate accounting basis was recommended to the large Malagasy municipalities. However, it is important to note that this accounting reform is unknown to most of the related parties (CSC 2003). Without having been applied by the municipalities, the PCOP 2000 was abolished and has been replaced by the PCOP 2006 (CSC 2003). According to this second reform, the full accrual accounting is recommended to the large municipalities. This accounting reform was supported by the organic law (LOLF 2004), promulgated by ministerial decrees (2005-210 of April 2005 for the Chart of Accounts) and orders (6458/2005 of June 2005 for the application guide). In spite of these official enactments, this new accounting arrangement is, until 2007, unknown to Malagasy mains reformers, such as the municipalities, the officials in the Ministry of Finance and the Ministry of Decentralisation. The problematic issue studied in this paper derives from this observation and is formulated as follows: Why is the accrual accounting still unknown to Malagasy municipalities in spite of its official enactment in 2004?

\section{Lüder's contingency model}

In the beginning of the 1990s, Lüder developed a contingency model to explain the reasons why some governments succeed in implementing accounting reform whereas others failed. In order to bring a further clarification, Lüder's contingency model refers to stimuli, the key actors, the institutional organisation and the implementation strategy as variables of the success and failure of the implementation of the accounting change (see Annex 1).

\subsection{The stimuli}

Stimuli are essentially events which are the precondition of the reform decision. These events are not discrete: they are supported by the media or nourish the collective debates as being academic and political (Lüder, 1992, 2000 and 2004; Christensen, 2001). The stimuli affect the top promoters, such as politicians or officials. According to Lüder (1992, 2000 and 2002) and Chan (2006), they may have resulted from the international convergence towards accounting harmonisation, the international move to NPM, the financial crisis or the donors' conditionality.

\subsection{The reformers}

The stimuli mobilise the key promoters, which may be the politicians, the state officials, the technician implicated in the reform process, the epistemic community and the information users (Luder, 1992):

- the political influence has an important weight in sustaining and validating the reform decision; 
- the agents technically implicated in the reform process are the regulation authority, the governmental authority and the accounting professional body; they are in charge of elaborating the normative referential;

- the epistemic community is in charge of the reflection to the reform concept;

- the information users exercise influence on the other reformers.

\subsection{The institutional organisation}

According to Lüder, the success or the failure of the accounting reform depends also on the institutional organisation, such as the state structure, the culture or the public function. On the basis of this assertion, Lüder (1992) proposes that the implementation of accounting innovation is more successful in the context of the domination of the professional accountants than in the context of the bureaucrat monopolisation. Other authors, such as Torres and Pina (2003) argue that the integration of accrual accounting is more difficult in the context of bureaucratic structures than in the context of decentralised structures.

\subsection{The implementation strategy}

The strategy of implementing accounting innovation is also important because of its nature, in facilitating or hindering the implementation process. According to Lande (2006), the implementation of a central reform guide is more successful than the disparate implementation. And according to Lüder (1992), the authoritative implementation is less successful than participative implementation.

As shown in Table 1, Lüder's contingency model is used by many researchers working in the field of accounting reform in the public sector.

Table 1 - A synopsis of recent studies based on Lüder's contingency model

\begin{tabular}{|c|c|c|}
\hline Authors & Contingency variable & Period \\
\hline $\begin{array}{l}\text { El-Batanoni and Jones } \\
\text { Likierman } \\
\text { Montesinos and Bargues } \\
\text { Pallot } \\
\text { Khumawala } \\
\text { Monsen and Nasi } \\
\text { Yamamoto } \\
\text { Godfrey et al. }\end{array}$ & $\begin{array}{l}\text { Stimuli, key actors and implementation } \\
\text { barriers }\end{array}$ & $\begin{array}{l}1996 \\
1996 \\
1996 \\
1996 \\
1997 \\
1998 \\
1999 \\
1996-2001\end{array}$ \\
\hline Lüder & $\begin{array}{l}\text { Stimuli, key actors, strategy, institutional } \\
\text { organisation, implementation barriers }\end{array}$ & $1990-2004$ \\
\hline $\begin{array}{l}\text { Jaruga and Nowak } \\
\text { Lande } \\
\text { Ouda } \\
\text { Godfrey et al. }\end{array}$ & $\begin{array}{l}\text { Stimuli, key actors, strategy and institutional } \\
\text { organisation }\end{array}$ & $\begin{array}{l}1996 \\
2004 \\
2003-2006 \\
1996-1999-2001- \\
\text { CIGAR 2005 }\end{array}$ \\
\hline
\end{tabular}




\begin{tabular}{|l|l|l|}
\hline \multicolumn{1}{|c|}{ Authors } & \multicolumn{1}{c|}{ Contingency variable } & \multicolumn{1}{c|}{ Period } \\
\hline Pollit and Bouckaert & $\begin{array}{l}\text { Socio-economic context, political system, } \\
\text { stimuli, key actors, administrative structure }\end{array}$ & $\begin{array}{l}2000 \\
\text { CIGAR 2005 }\end{array}$ \\
\hline $\begin{array}{l}\text { Christensen } \\
\text { Marwata } \text { et al. }\end{array}$ & Key actors & 2002 \\
\hline Chan & Key actors and institutional organisation & $\begin{array}{l}1995-1999- \\
2006\end{array}$ \\
\hline Manzurul & Culture & CIGAR 2005 \\
\hline
\end{tabular}

\section{Methodology}

According to Lüder's contingency model, the implementation of an accounting reform is a long process, beginning with the motivations of the main promoters and ending with the success or the failure of the accounting reform. In this study, we are not interested in the full process of reform as proposed by Lüder. We will only focus on the reasons why the new accounting arrangement has not been recognised after promoters in the central government were motivated to adopt it after it has been promulgated by successive laws and decrees since 2004. Then, in this study, we integrate a part of Lüder's model, specifically the effects of the actors' behaviour and the accounting organisation in the implementation of accounting change in Malagasy municipalities.

To bring further clarification to our problem, we have adopted the qualitative approach. As determined by this approach, we have collected some opinions and compared the different opinions with political discourses and different official documents (laws, decrees and reports). In this study, we have interviewed two categories of persons related to the public sector accounting change: the central government's actors and the municipalities' actors.

\subsection{The central government's interlocutors}

As shown in the following tables (Tables 2 to 5) we have collected opinions from four categories of interlocutors from 2004 to 2006. They are actors in:

- the Ministry of Finance (MEFB), they have participated in the development of the new Chart of Accounts within the $\operatorname{CSC}^{1}$ (national council of accounting harmonisation);

- the Ministry of Decentralisation (MDAT);

- the Ministry of Interior and Administrative Reform (MIRA);

- the body of certified accountants (OECFM) ${ }^{2}$.

\footnotetext{
${ }^{1}$ CSC: Conseil Supérieur de la Comptabilité - national council of accounting harmonisation.

${ }^{2}$ OECFM : Ordre des Expert Comptable et Financiers de Madagascar (certified accountant association).
} 
Table 2 - The technical promoters of the new Chart of Accounts recommending the accrual accounting in the CSC

\begin{tabular}{|c|c|c|c|c|}
\hline Function & Number & $\begin{array}{c}\text { Entity } \\
\text { represented }\end{array}$ & $\begin{array}{c}\text { Interviewing } \\
\text { period }\end{array}$ & Interview's objectives \\
\hline $\begin{array}{l}\text { Certified } \\
\text { Accountant } \\
\text { working within } \\
\text { the CSC }\end{array}$ & 1 & OECFM & $\begin{array}{l}\text { March } 2004 \\
\text { September } \\
2006\end{array}$ & \multirow{2}{*}{$\begin{array}{l}\text { - Interactions with the other } \\
\text { CSC members at the time of the } \\
\text { development of the new chart of } \\
\text { accounts (PCOP 2006). } \\
\text { - Perception of accrual accounting } \\
\text { diffusion and its applicability at } \\
\text { the level of municipalities } \\
\text { - Interactions with the other } \\
\text { MEFB civil servants at the time } \\
\text { of diffusion and implementation } \\
\text { of accrual accounting in the } \\
\text { municipalities }\end{array}$} \\
\hline $\begin{array}{l}\text { Civil servant } \\
\text { within the CSC }\end{array}$ & 4 & MEFB-DCP* & $\begin{array}{l}\text { February } 2004 \\
\text { November } \\
2005 \\
\text { June } 2006\end{array}$ & \\
\hline Total & 5 & & & \\
\hline
\end{tabular}

* Direction de la Comptabilité Publique (Public Accounting Division).

At this stage of analysis, we have compared the opinions of technical promoters with that of other civil servants. This comparison is important because it allows us to know how these actors are interacting and how they are implicated in the implementation of the new accounting arrangement in all levels of State structure.

Table 3 - Civil servant supporters in the MEFB

\begin{tabular}{|c|c|c|c|}
\hline Function & Number & Period & Interview's objectives \\
\hline State inspector & 1 & $\begin{array}{l}\text { June } 2006 \\
\text { November } 2004\end{array}$ & \multirow{4}{*}{$\begin{array}{l}\text { - Appreciation of accrual } \\
\text { accounting applicability in } \\
\text { the municipalities } \\
\text { - Legal disposition of } \\
\text { the accrual accounting } \\
\text { implementation } \\
\text { - Interactions with the } \\
\text { CSC, OECFM, the } \\
\text { department of information } \\
\text { systems at the time of the } \\
\text { accrual implementation } \\
\text { - the diffusion mode of the } \\
\text { accrual accounting concept } \\
\text { to the municipalities }\end{array}$} \\
\hline $\begin{array}{l}\text { Manager of information system } \\
\text { division }\end{array}$ & 1 & September 2006 & \\
\hline $\begin{array}{l}\text { Manager of public accounting } \\
\text { division }\end{array}$ & 1 & September 2006 & \\
\hline $\begin{array}{l}\text { Agent in the division of public } \\
\text { accounting }\end{array}$ & 1 & January 2007 & \\
\hline Total & 4 & & \\
\hline
\end{tabular}


To ensure better coherence in the implementation approach, other civil servants in the other ministries, such as the MDAT and the MIRA, have to be implicated. Because of their financial control responsibilities, they are in direct contact with the municipalities. So they can assure and facilitate the diffusion of the new accounting arrangement to the municipalities.

Table 4 - Civil servants within other ministries: MDAT and MIRA

\begin{tabular}{|c|c|c|c|c|}
\hline Function & No. & Period & Entity & Object of interviews \\
\hline $\begin{array}{l}\text { Manager of the } \\
\text { municipalities' } \\
\text { financial support } \\
\text { division }\end{array}$ & 1 & March 2006 & \multirow{3}{*}{ MDAT } & \multirow{4}{*}{$\begin{array}{l}\text { - the department's responsibility } \\
\text { - Interaction with the MEFB and/ } \\
\text { or the CSC in the implementation } \\
\text { of the accrual accounting in the } \\
\text { municipalities } \\
\text { - the administrative disposition } \\
\text { taken at the level of the ministry } \\
\text { and the department in order to } \\
\text { implement the accrual accounting } \\
\text { in the municipalities } \\
\text { - the nature, extent and content } \\
\text { of the accounting training } \\
\text { administered to the municipalities } \\
\text { - Perception of the applicability } \\
\text { of the accrual accounting in the } \\
\text { municipalities } \\
\text { - the extent and the nature of } \\
\text { financial control exercised within } \\
\text { the municipalities }\end{array}$} \\
\hline $\begin{array}{l}\text { Agent of the training } \\
\text { division }\end{array}$ & 1 & $\begin{array}{l}\text { November } \\
2004 \\
\text { March } 2006 \\
\end{array}$ & & \\
\hline $\begin{array}{l}\text { Responsible entity } \\
\text { in the follow-up and } \\
\text { assessment division }\end{array}$ & 1 & $\begin{array}{l}\text { November } \\
2004 \\
\text { March } 2006\end{array}$ & & \\
\hline $\begin{array}{l}\text { Manager of } \\
\text { information system } \\
\text { division }\end{array}$ & 1 & June 2005 & MIRA & \\
\hline
\end{tabular}

The interview's results are finally compared with those held with the other stakeholders, such as the OECFM or other civil servants within the MEFB, as shown in the following table.

Table 5 - Other stakeholders

\begin{tabular}{|c|c|c|c|c|}
\hline Function & No. & Period & Entity & Object of interviews \\
\hline Accountant working the CSC & 1 & \begin{tabular}{|l} 
Feb 2004 \\
August 2006
\end{tabular} & $\begin{array}{l}\text { CSC and } \\
\text { OECFM }\end{array}$ & \multirow{7}{*}{$\begin{array}{l}\text { - Perception of the } \\
\text { current practice of } \\
\text { public accounting } \\
\text { - Perception of the } \\
\text { adoption of accounting } \\
\text { applicability by the } \\
\text { municipalities } \\
\text { - Diffusion plan of the } \\
\text { PCOP } 2006 \text { within the } \\
\text { Malagasy public sector }\end{array}$} \\
\hline $\begin{array}{l}\text { Civil servant representing the } \\
\text { MEFB within the CSC }\end{array}$ & 1 & August 2006 & $\begin{array}{l}\text { CSC and } \\
\text { MEFB }\end{array}$ & \\
\hline OECFM Vice-President & 1 & Sept 2006 & OECFM & \\
\hline OECFM President & 1 & Sept 2006 & $\begin{array}{l}\text { CSC and } \\
\text { OECFM }\end{array}$ & \\
\hline Financial magistrate within MEFB & 1 & Sept 2006 & MEFB & \\
\hline $\begin{array}{l}\text { Second General Manager within } \\
\text { the INSTAT }\end{array}$ & 1 & August 2006 & MEFB & \\
\hline Councillor within the MEFB & 1 & Sept 2006 & MEFB & \\
\hline Total & 7 & & & \\
\hline
\end{tabular}




\subsection{The municipalities' interlocutors}

In order to obtain coherent information, we have collected some opinions from responsible entities within the municipalities. Between 2005 and 2006, we interviewed fifty-two interlocutors, as shown in the Table $6^{3}$.

Table 6 - Municipality interlocutors

\begin{tabular}{|c|c|c|}
\hline Function & No. & Object of interviews \\
\hline Mayor & 23 & \multirow{7}{*}{$\begin{array}{l}\text { - Quality of financial information } \\
\text { - Implementation of accrual accounting }\end{array}$} \\
\hline $\mathrm{CS}$ & 2 & \\
\hline MA & 18 & \\
\hline FAM & 3 & \\
\hline $\mathrm{MC}$ & 1 & \\
\hline Public accountant & 2 & \\
\hline Councillors & 3 & \\
\hline Total & 52 & \\
\hline
\end{tabular}

List of abbreviations - CS: Chief of Staff; MA: Municipality Accountant; FAM: Financial and Administrative Manager; MC: Management Controller; PA: Public Accountant; Counc: Councillor.

\section{Findings}

From these interviews we have found that the one major obstacle holding back the implementation of accrual accounting in the municipalities is the failure of the diffusion mechanism. This failure is a matter of the promoter's actions and the public accounting organisation.

\subsection{The effects of interaction between the promoters on the diffusion of accrual accounting in the municipalities}

The interactions between promoters fail because:

- there is a lack of synergy between civil servants and certified accountants within the CSC at the moment of conception of the normative referential and at the moment of its implementation;

- there is a lack of political commitment at the level of the central government.

\subsubsection{The lack of synergy between certified accountants and civil servants}

In order to converge to the international accounting harmonisation, a new normative referential, the PCOP 2006, was established in place of the old one, the PCOP 2000. It is designed on the basis of the private entity accounting rules and it recommends

\footnotetext{
${ }^{3}$ Further details on the municipalities visited are presented in Annex 2.
} 
the adoption of full accrual accounting to all public large entities. The design of this new Chart of Accounts was undertaken, at the beginning of 2003, by the Ministry of Finance (MEFB) through the CSC (national body of accounting harmonisation). Within the CSC, the working group which is in charge of this mission is formed by one certified accountant, member of the OECFM, and seven civil servants, representing the MEFB and the MDAT, as displayed in Table 7.

Table 7 - Member of the working group

\begin{tabular}{|l|l|l|}
\hline \multicolumn{1}{|c|}{ Group members } & \multicolumn{1}{c|}{ Entity } & \multicolumn{1}{c|}{ Attributions } \\
\hline Accountant & OECFM & Group's framer \\
\hline Civil servant & Division of public treasury & Group's line chief \\
\hline Civil servant & Division of public accounting & Technical concept \\
\hline Civil servant & Division of public accounting & Technical concept \\
\hline Civil servant & Division of public accounting & Technical concept \\
\hline Civil servant & Court of Auditors & Technical concept \\
\hline Civil servant & MDAT & Technical concept \\
\hline Civil servant & CAE* & Technical concept \\
\hline
\end{tabular}

* CAE: Communauté d'Aide Extérieur (Community of External Support)

As shown in this table, the accountant is the group's framer; he ensures that the group's work conforms to international accounting standards. The other members ensure the concept of the new normative referential.

As symbolic as it may appear, the certified accountants' actions are more meaningful than those of the civil servants at the moment of the concept of the new chart of accounts. The members of the working group we have interviewed agree that it has resulted from the works of other certified accountants acting discreetly. These works are based on the private sector's normative referential, the PCG 2005. It is important to note that the latter is the root of all sector charts of accounts and it is designed according to the IAS - IFRS. In practice, the civil servants have no role in the elaboration of the normative referential. Therefore, some of them learnt about it only after its official enactment, at the beginning of 2005, as shown in Table 8.

Table 8 - How members are involved at the PCOP 2006 concept stage

\begin{tabular}{|l|c|c|c|}
\hline \multicolumn{1}{|c|}{ Participation in the concept of PCOP 2006 } & No. & Accountant & Civil servants \\
\hline $\begin{array}{l}\text { Learning about content of the new chart of accounts } \\
\text { during its conception }\end{array}$ & 2 & 1 & 1 \\
\hline $\begin{array}{l}\text { Learning about the content of the new chart of } \\
\text { accounts after its official enactment }\end{array}$ & 6 & 0 & 6 \\
\hline Total & 8 & 1 & 7 \\
\hline
\end{tabular}

The effect of this lack of dialogue within the CSC working group is the development of a Chart of Accounts which is not understood by its own creators. On the one hand, without knowing the public sector specificity the certified accountants established the new chart of accounts. They have also based their works on the rules of the private sector accounting. On the other hand, without understanding the accrual accounting concept 
and its stakes, the civil servants are in charge of implementing it in all levels of the State structure. Thus, it is logical if the latter seem to have some difficulties in diffusing and convincing their colleagues, at all government levels, to adopt such arrangement.

\subsubsection{The lack of political will at the level of central government}

Considering that Madagascar has a bureaucratic system centralised in the presidency level (World Bank 2005), it is logical that reforms affecting the state are legitimated and endorsed by the political managers in the central government. These political managers may be the president himself or the ministers. According to the semi-guided interviews with the civil servants within the MEFB and the other stakeholders, we can advance that the lack of political commitment is the major reason hindering the diffusion and the implementation of accrual accounting in the municipalities.

Since its elaboration and until now, from 2003 to 2007, no political discourses have been presented and no political interests were manifested in the sense of modernizing the public accounting or in the sense of benefits gained from the accrual accounting in the public sector. That is the reason why some politicians, such as the MEFB minister and the MEFB chief of staff, were indifferent to the implementation of such reform in the municipalities. Therefore, some officials within the MEFB argue that such innovation is not applicable within the municipalities and others argue that it depends on political will. These arguments are summarised in Table 9.

Table 9 - Assessment of the implementation of accrual accounting by the municipalities

\begin{tabular}{|l|c|l|l|}
\hline \multicolumn{1}{|c|}{ Title } & No. & Category & \multicolumn{1}{|c|}{$\begin{array}{c}\text { Implementation of } \\
\text { accrual accounting } \\
\text { by the municipalities }\end{array}$} \\
\hline Minister of MEFB & 1 & Politician & Indifferent \\
\hline Chief of Staff of the MEFB & 1 & Politician & Indifferent \\
\hline $\begin{array}{l}\text { Official in charge of public expenditure in } \\
\text { the CSC }\end{array}$ & 1 & Civil servant & Indifferent \\
\hline Financial Magistrate & 1 & Civil servant & Indifferent \\
\hline Manager of IS division in the MEFB & 1 & Civil servant & Indifferent \\
\hline Finance inspector & 2 & Civil servant & Not applicable \\
\hline Chief of ACCT department in the MEFB* & 1 & Civil servant & Not applicable \\
\hline $\begin{array}{l}\text { Second General Manager of the } \\
\text { INSTAT** in the MEFB }\end{array}$ & 1 & Civil servant & Not applicable \\
\hline Public accountant in the Treasury & 1 & Civil servant & Not applicable \\
\hline $\begin{array}{l}\text { Manager of public accounting division in } \\
\text { the MEFB }\end{array}$ & 1 & Civil servant & Not applicable \\
\hline $\begin{array}{l}\text { Agent in the public accounting division in } \\
\text { the MEFB }\end{array}$ & 2 & Civil servant & Applicable with political will \\
\hline $\begin{array}{l}\text { Line Chief of PCOP 2006 working group } \\
\text { in the CSC }\end{array}$ & 1 & Civil servant & Applicable with political will \\
\hline Total & 14 & & \multicolumn{2}{|l}{} \\
\cline { 1 - 2 } & &
\end{tabular}

* ACCT: Agence Comptable Central du Trésor (Treasury Central Accounting Agency)

** INSTAT: Institut National de la Statistique (National Institute of Statistics) 
Since key actors in the central government are not implicated, no more information is going to be diffused and the municipality actors, which have a habit of aligning their politics with those of the central government, are automatically uninterested. Moreover, contrary to other programs, such as the struggle against AIDS and malaria or the institution of new laws regulating the ADN test or even the implementation of new agricultural techniques, which benefit political discourses, the implementation of accrual accounting is not included in the national priorities. Then, it is not included in national programs and it remains not advocated in the $\operatorname{DSRP}^{4}(2005,2006)$ or in the MAP5 (2007). So it does not appear in any reform programs financed by the international institutions such as the World Bank and/or the European Union. These are the reasons why among the 52 municipality interlocutors we have interviewed, $69 \%$ are satisfied with the quality of financial information obtained by using the cash model. $71 \%$ feel that they are able to manage the municipalities' affairs with this system, so they are not motivated to change the accounting practice (Tables 10 to 12). The argument they have advanced is that such innovation is not described as fundamental by the central government's politicians.

Table 10 - Assessment of the quality of financial information obtained by using the cash system

\begin{tabular}{|l|c|c|}
\hline \multicolumn{1}{|c|}{ Assessment of the financial information quality } & No. & \% \\
\hline Satisfied & 36 & $69 \%$ \\
\hline Not satisfied & 16 & $31 \%$ \\
\hline Total & 52 & $100 \%$ \\
\hline
\end{tabular}

Table 11 - Assessment of the direction method

\begin{tabular}{|l|c|c|}
\hline \multicolumn{1}{|c|}{ Mangement / Administration } & No. & \% \\
\hline Management & 37 & $71 \%$ \\
\hline Administration & 15 & $29 \%$ \\
\hline Total & 52 & $100 \%$ \\
\hline
\end{tabular}

Table 12 - Motivation degree to the accounting reform within the municipalities' interlocutors

\begin{tabular}{|l|c|c|}
\hline Motivation degree to the accounting reform & No. & \% \\
\hline Indifferent & 37 & $71 \%$ \\
\hline Not motivated & 9 & $9 \%$ \\
\hline Very motivated & 6 & $6 \%$ \\
\hline Total & 52 & $100 \%$ \\
\hline
\end{tabular}

\footnotetext{
${ }^{4}$ DSRP: Document of strategy of poverty reduction (from 2003 to 2006).

${ }^{5}$ MAP: Madagascar Action Plan for five years (from 2007 to 2012).
} 
The major contributions of the political commitment are to diffuse the benefit and the spirit of accrual accounting to all actors in the public sector, to legitimate the administrative reforms undertaken in this way and to mobilize all actors concerned by the public sector accounting.

\subsection{The effects of the accounting organisation on the adoption of accrual accounting in the municipalities}

In the middle of 2004, the Ministry of Finance elaborated an organic law, LOLF 2004, which determines that the public entities have to practice accounting in the same way as the private entities. In spite of this initiative, the other laws underlying the public sector accounting did not undergo any modifications. The cash receipts and disbursements continue to dominate the accounting regulation, and legal and regular financial controls attenuate the use of the cash accounting model. According to decree 2005-003 of January 2005 determining the public sector accounting regulation, the law 95-005 of June 1995 establishing the budgetary regulation of decentralized community, there is a separation between the attributions of public accountant and the official in charge of public expenditure. The public accountant holds the general account of the municipality but he is not the main actor needing this kind of information. The municipality's officials keep the cash budgetary accounting, which does not provide any more financial information to manage the municipality.

The Ministry of Finance is in charge of the public bookkeeping and financial control. In its role, it employs the public accountant within treasuries to keep the municipalities' funds, to hold the municipalities' bookkeeping, and to record the municipalities' equipment. The municipalities are in charge of holding municipalities' bookkeeping according to the accrual accounting rules. But, in practice, as disposed by the MEFB instruction no. 06-32-G of December 2006, the public accountant registers the municipalities' financial operations according to moderate cash accounting: the expenses are recorded on the basis of the mandates and the receipts on the basis of the receipt orders.

According to the same regulations, the accounting attribution of the official in charge of public expenditure, for example the municipality's mayor, is limited to holding the administrative accounting: budget and the budget execution reporting. The budget recapitulates the cash receipts and disbursements in terms of investments and running affairs. Then, the budget execution reporting recapitulates equally the same operations.

In short, with the current statutory provision, the accrual accounting cannot be diffused: the public accountant, whose responsibility is similar to a cashier's, is in charge of the municipalities' bookkeeping according to accrual basis, but the actual legal provision doesn't foresee a procedure for the recording of specific operations, such as the physical assets or assets depreciation. On the contrary, the official in charge of public expenditure, who needs further information to manage the municipalities, is left with manipulating limited information: they are established on the basis of the cash model.

In addition, the control mechanism is more appropriate to cash accounting practice. According to law 2005-025 of April 2003, the decree 2004-573 of June 
2004 and the law 95-005 of June 1995, the financial control exercised by the MEFB, the MIRA and the MDAT in the municipalities all focus on the regularity and legality of the cash operations undertaken by the officials. There is no legal provision for the control in terms of financial audit or in term of conformity with the new chart of account established by the CSC. In order to comply with legal provision in force, the municipalities' officials pay more attention to the budget and the budget execution reporting. In others words, they are led to grant more importance to the cash accounting practice rather than to accrual accounting.

\section{Conclusion}

On the one hand, the actions of the national body of accounting harmonisation, the CSC, and the professional body, the OECFM, are not significant to engage a real process of accounting reform. In addition, the lack of dialogue between the civil servants and the certified accountants, who are in charge of the elaboration of accounting normative referential within the CSC, leads to establishment of a chart of accounts unknown to its creators. As such, it seems difficult to convince the other actors to engage in a real process of accounting reform.

On the other hand, in the context of the bureaucratic system centralised in the level of presidency, the political implication is useful to support the accounting reform to all levels of government structure. The political supports legitimate, also, all initiatives engaged in the sense of the implementation of the accounting reform both at the level of central government and at the level of municipalities. Then, without political commitment, the accounting reform program cannot become a national priority and will not benefit, automatically, from funding from the international body. Then, it is logical that major accounting actors, such as civil servants in the central government and municipalities officials, are not motivated to reform the accounting practice. Evidence of this is shown below:

- some statutory provisions relative to public sector accounting remained unmodified and others are badly solved:

- the financial control mechanism still focuses on cash basis;

- there is no legal provision regulating the recording of the physical assets or assets depreciation;

- there is no legal provision for the financial audit;

- the municipalities' officials content to manipulate cash financial information, but they need more detailed financial information to manage the municipalities.

\section{References}

Adhemar, P. (2005), International Federation of Accountants, International Public Sector Accounting Standards Boards, Background and Update, CIGAR Conference, Poitiers, April 2005, 36.

Albafouille, F. and Ramangasoavina, A. (1964), Le contrôle des comptes à Madagascar, Imprimerie Nationale Antananarivo, 15 . 
Andriamihaja, L. (1988), L'organisation financière de Madagascar, Imprimerie d'ouvrages éducatifs, Ankatso, Antananarivo.

Azan, W. (2002), Evolution des systèmes comptables, contrôle externe et réseaux de culture, Revue de l'Association Francophone de la comptabilité, Volume 2, 29-50.

Bescos, P.; Cauvin, E. and Mendoza, C. (2004), Critiques du budget: une approche contingente, Revue de l'Association Francophone de la comptabilité, Vol. 1, 165-185.

Chan, J. L. (2003), Government Accounting: An Assessment of Theory, Purposes and Standards, Public Money and Management.

Chan, J. L. (2006), Government Accounting Reform in Developing Countries, in Lande, E. and Scheid, J. C. (eds.), Accounting Reform in the Public Sector: Mimicry, Fad or Necessity, Edition ECM, 31-41.

Christensen, M. (2001), Public Sector Accrual Accounting, Who Made the Emperor's Clothes?, Asian Pacific Interdisciplinary Research in Accounting (APIRA) Conference.

El-Batanoni, K. and Jones, R. (1996), Governmental Accounting in the Sudan, Research in Governmental and Nonprofit Accounting, Vol. 9, 209-218.

Eveno, P. (1997), Les pouvoirs urbains face aux technologies d'information et de communication, Presses universitaires de France.

Ezzamel, M. (1994), Organisational Change and Accounting: Understanding the Budgetary System in its Context, Organisation Studies, 29, 213-240.

Ezzamel, M.; Hyndman, N.; Johnsen, A.; Lapsley, I. and Pallot, J. (2004), Has Devolution Increased Democratic Accountability?, Public Money and Management, Vol. 24, No. 3, 145-152.

Ghiglione, R. and Blanchet, A. (1991), Analyse de contenu et contenus d'analyse, DUNOD, Paris.

Godfrey, A.; Devlin, P. and Merrouche, M. (2001), A Diffusion-Contingency Model for Governmental Accounting Innovations, in Bac, A. (ed.), International Comparative Issues in Government Accounting, Dordrecht: Kluwer Academic Publishers, 279-296.

Godfrey, A.; Devlin, P. and Merrouche, M. (1996), Governmental Accounting in Kenya, Tanzania and Uganda, Research in Governmental and Nonprofit Accounting, Vol. 9, 193-208.

Haldma, T. (2006), Uneven Way of Integration of Governmental Accounting into National Accounting System: Evidence from Estonian Municipalities, in Lande, E. and Scheid, J. C. (eds.), Accounting Reform in the Public Sector: Mimicry, Fad or Necessity, Edition ECM, 163-175.

Hughes, J. and Minovski (2004), A Plan for Implementation of International Public Accounting Standards in Developing Countries and Economy in Transition, Public Fund Digest, Vol. 04 No. 01. International consortium in governmental financial management, Washington DC, February 2004, 32-52.

International Federation of Accountants (2003), Handbook of the International Public Sector Accounting Standards, PSC-IPSAS1, 137.

Jarvenpaa, M. (1998), Management Accounting and Strategy. Functional and Institutional Perspectives: A Case Study, 21st European Accounting Association Congress.

Jorge, S.; Carvalho, J. and Fernandes, M. J. (2006), Compliance with the New System of Local Government Accounting in Portugal: Empirical Evidence and Reasons for Non-Compliance, in Lande, E. and Scheid, J. C. (eds.), Accounting Reform in the Public Sector: Mimicry, Fad or Necessity, Edition ECM, 145-162.

Khumawala, S. (1997), Public Sector Accounting in India: A Historical Review and an Analysis since Independence to the Economic Reforms of the Nineties, Journal of Public Budgeting, Accounting and Financial Management, Vol. 9, No. 2, 305-330.

Konstantin, T. (2004), Modernizing Russian Federal Accounting, A paper of PhD Course first draft.

Lande, E. (2003), Le système d'informations des communes permet-il de mesurer les risques financiers?, Revue du Trésor, février 2003.

Lande, E. (2006), Accrual Accounting in the Public Sector: Between Institutional Competitiveness and Search for Legitimacy, in Lande, E. and Scheid, J. C. (eds.), Accounting Reform in the Public Sector: Mimicry, Fad or Necessity, Edition ECM, 19-30. 
Lehman, G. (2003), A Critical Perspective on the Harmonisation of Accounting in a Globalising World, Academic Press, 1-18.

Likierman, A. (1996), The UK Government's Accounting and Budgeting Revolution, Research in Governmental and Nonprofit Accounting, Vol. 9, 303-322.

Lüder, K. (2002), Research in Comparative Accounting over the Last Decade: Achievements and Problems, in Montesinos and Vela (eds.), Innovations in Governmental Accounting, Boston: Kluwer.

Macmillan, G. (2003), Improving Government Financial Reporting: The Window to Good Governance, The Governance Brief, ADB (September 2003).

Manzurul, A. and Nandan, R. (2005), Public Sector Reform and Accounting Change in a Cultural Environment, CIGAR Conference, Poitiers.

Matthew, O. (2003), Deploying Financial Management Systems in Developing Nations. The International Consortium on Governmental Financial Management, Public Fund Digest, Volume 3, No. 02, Washington DC, 8-20.

Maurel, C. and Gains, A. (2005), The French Local Authorities' Experiences in the Computerization of the Accounting and the Budgeting Systems, CIGAR Conference, Poitiers.

Merrouche, C. and Devlin, P. (2005), Local Government Accounting in Algeria: Anarchy or Modernity, CIGAR Conference (Poitiers).

Monsen, N. and Nasi, S. (1998), The Contingency Model of Governmental Accounting Innovations: A Discussion, The European Accounting Review, Vol. 7, No. 2, 275-288.

Montesinos, V. and Bargues, J. (1996), Governmental Accounting in Spain: Evolution and Reforms, Research in Governmental and Nonprofit Accounting, Vol. 9, 219-38.

O’Brien (2003), Good Governance: Efforts by Donor Agencies, Public Fund Digest, Vol. 3, No. 2, International Consortium (August 2003), Washington, D.C, 20-29.

Obert, R. (2003), Pratique des normes IAS/IFRS, Comparaison avec les règles françaises et les US GAAP, Edition DUNOD, Paris.

Ouda, H. (2003), Accrual Accounting in the Government Sector Background, Concepts, Benefits and Costs, Department of Accounting and Accountancy, Public Fund Digest, Vol. 3, No. 2, International Consortium on Governmental Financial Management Washington, 52-58, 91.

Ouda, H. (2006), Transition Requirements of Accrual Accounting in the Public Sector of Developed and Developing Countries: An Empirical Investigation with Special Focus on the Netherlands and Egypt, in Lande, E. and Scheid, J. C. (eds.), Accounting Reform in the Public Sector: Mimicry, Fad or Necessity, Edition ECM.

Pallot, J. (2001a), Transparency in Local Government, Antipodean Initiatives, The European Accounting Review, Vol. 10, No. 3, 645-660.

Pallot, J. (2001b), A Decade in Review: New Zealand's Experience with Resource Accounting and Budgeting, Financial Accountability and Management, Vol. 17, No. 4, 383-400.

Pettersen, J.; Rotefoss, B.; Jonsson, S. and Korneliussen, T. (2005), Nordic Management and Business Administration Research, quo vadis?, Norway, GRI (Gothenburg Research Institute) report.

PNUD (2001), Coopération du gouvernement malgache et le Programme des Nations Unis pour le Développement, Programme MAG 197/007-DAP 1, Guide du maire, gouvernance et politiques pour le développement humain durable, juin 2001, mis à jour et réédité en février 2004, DL No. 001-02/04, 67-73.

Rakoto, H. (2007), Innovation comptable au sein des communes malgaches: la cas de l'adoption de la comptabilité d'engagement, Université de Poitiers.

Razafimahatratra, P. (2005), Mise en place d'un comité technique pour améliorer la fiscalité locale, Les nouvelles, $\mathrm{N}^{\circ} 0468 \mathrm{du} 07$ septembre 2005, 03, 23.

Torres, L. and Pina, V. (2003), Reshaping public sector accounting, Revue canadienne des sciences de l'administration, 334-350.

Van Helden, J. (2003), A Review of Governmental Accounting Reform, Systems, Organisation and Management, University of Groningen, 1-40. 
Wynne, A. (2003), Do Private Sector Financial Statements Provide a Suitable Model for Public Accounts?, Public Law and the Modernizing State Conference, Oeiras.

Wynne, A. (2005), Public Financial Management Reform in Developing Countries, Local Solutions for the Local People, CIGAR Conference, Poitiers.

Yamamoto, K. (1999), Accounting System Reform in Japanese Local Governments, Financial Accountability and Management, Vol. 15, No. 3 and 4, 291-307.

\section{Statutory provision}

- Decree 2004-573 of June 2004, on the general inspection of finances.

- Decree 2005-003 of January 2005, on the public sector accounting regulation.

- Decree 2005-210 of April, 2005, PCOP 2006.

- Law 2001-025 of April 2003, on financial court.

- Law 95-005 of May 1995, on the collectivity's budgetary system control.

- LOLF No. 2004-007 of July 2004, on organic finances laws.

- Order 6458/2005 of June 2005, a collectivity's PCOP 2006 application guide.

\section{Political discourses}

- Radavidson A., Minister of Economy, Finance and Budget, on investment on the matter of road infrastructures, Mahajanga, June 2004.

- Ramandimbiarison, Z., Deputy Prime Minister, on good governance and transparency, Tananarive, 2004.

- Ravalomanana, M., President of the Republic of Madagascar, on DSRP implementation, Tananarive, 2004.

- Ravalomanana, M., President of the Republic of Madagascar, on MAP's presentation, Tananarive, January 2007.

- Sylla. J, Prime Minister, on the programme of implementation of state's politics, Tananarive, March 2003. 
Annex 1 - Lüder's contingency model

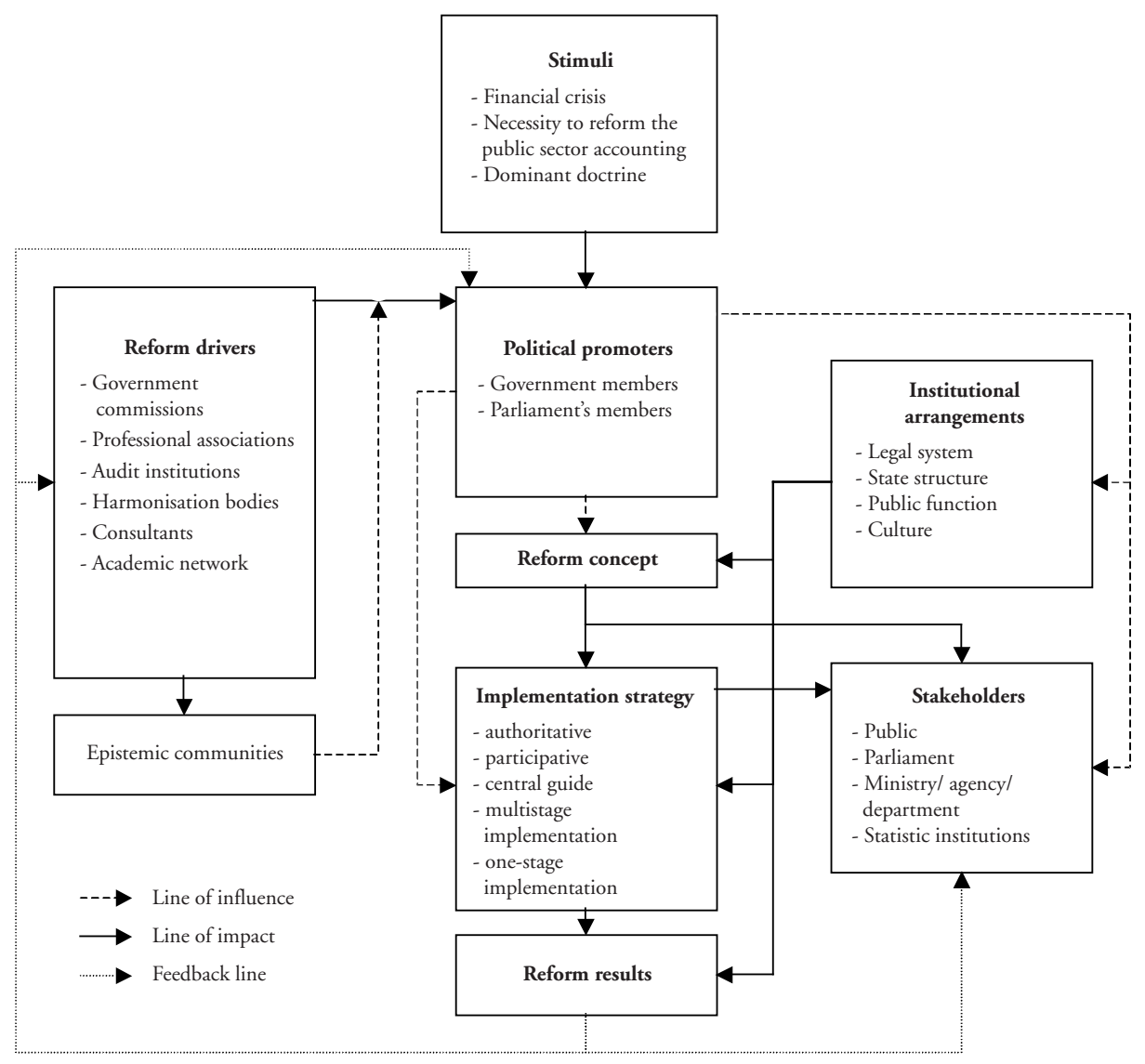

Source: Lüder (2002) 
Annex 2 - Details of municipalities visited

\begin{tabular}{|c|c|c|c|c|c|c|c|c|c|c|}
\hline MUNICIPALITY & Province & Category & Mayor & CS & СТВ & FAM & CG & PA & Cons & TOTAL \\
\hline Alarobia Ambatomanga & Tana & rur 2 nd cat & 1 & 0 & 1 & 0 & 0 & 0 & 0 & 2 \\
\hline Alasora & Tana & rur 2 nd cat & 1 & 0 & 1 & 0 & 0 & 0 & 0 & 2 \\
\hline Amabatolaona & Tana & rur 2 nd cat & 0 & 0 & 1 & 0 & 0 & 0 & 0 & 1 \\
\hline Amabatomena & Tana & rur 2 nd cat & 0 & 0 & 1 & 0 & 0 & 0 & 0 & 1 \\
\hline Ambanitsena & Tana & rur 2 nd cat & 0 & 0 & 1 & 0 & 0 & 0 & 0 & 1 \\
\hline Ambatomanga & Tana & rur 2 nd cat & 0 & 0 & 1 & 0 & 0 & 0 & 0 & 1 \\
\hline Ambohibao Sud & Tana & rur 2 nd cat & 1 & 0 & 0 & 0 & 0 & 0 & 0 & 1 \\
\hline Ambohimalaza & Tana & rur 2 nd cat & 1 & 0 & 1 & 0 & 0 & 0 & 0 & 2 \\
\hline Ambohimangakely & Tana & rur 2 nd cat & 2 & 0 & 2 & 0 & 0 & 0 & 0 & 4 \\
\hline Ambohitradrimoanala & Tana & rur 2 nd cat & 1 & 0 & 0 & 0 & 0 & 0 & 0 & 1 \\
\hline Ambohitrandriamanitra & Tana & rur 2 nd cat & 0 & 0 & 1 & 0 & 0 & 0 & 0 & 1 \\
\hline Ambohitrolonimahitsy & Tana & rur 2 nd cat & 1 & 0 & 0 & 0 & 0 & 0 & 0 & 1 \\
\hline Ambohitrony & Tana & rur 2 nd cat & 1 & 0 & 0 & 0 & 0 & 0 & 0 & 1 \\
\hline Ambohitseheno & Tana & rur 2 nd cat & 0 & 0 & 1 & 0 & 0 & 0 & 0 & 1 \\
\hline Ampaneva & Tana & rur 2 nd cat & 1 & 0 & 0 & 0 & 0 & 0 & 0 & 1 \\
\hline Ankazondandy & Tana & rur 2 nd cat & 1 & 0 & 0 & 0 & 0 & 0 & 0 & 1 \\
\hline Antsirabe & Tana & urb 1st cat & 1 & 0 & 0 & 0 & 0 & 0 & 0 & 1 \\
\hline Tana & Tana & urb no cat & 1 & 0 & 0 & 1 & 1 & 1 & 0 & 4 \\
\hline Fenoarivo/Alakamisy & Tana & rur 2 nd cat & 1 & 0 & 1 & 0 & 0 & 0 & 0 & 2 \\
\hline Fieferana & Tana & rur 2 nd cat & 1 & 0 & 0 & 0 & 0 & 0 & 0 & 1 \\
\hline Imerikanjaka & Tana & rur 2 nd cat & 1 & 0 & 0 & 0 & 0 & 0 & 0 & 1 \\
\hline Manjakandriana & Tana & rur 2 nd cat & 0 & 0 & 1 & 0 & 0 & 0 & 0 & 1 \\
\hline Miadanandriana & Tana & rur 2 nd cat & 1 & 0 & 0 & 0 & 0 & 0 & 0 & 1 \\
\hline Tanjombato & Tana & rur 2 nd cat & 1 & 0 & 0 & 0 & 0 & 0 & 0 & 1 \\
\hline Vilihazo & Tana & rur 2 nd cat & 0 & 0 & 1 & 0 & 0 & 0 & 0 & 1 \\
\hline Ambanja & Diégo & urb 2nd cat & 0 & 0 & 1 & 0 & 0 & 0 & 0 & 1 \\
\hline Antsiranana & Diégo & urb 1st cat & 0 & 0 & 0 & 1 & 0 & 0 & 1 & 2 \\
\hline Sahatona & Fianarantsoa & rur 2 nd cat & 1 & 0 & 0 & 0 & 0 & 0 & 0 & 1 \\
\hline Ankazomborona & Majunga & rur 2 nd cat & 1 & 0 & 0 & 0 & 0 & 0 & 0 & 1 \\
\hline Marovoay & Majunga & urb 2nd cat & 0 & 1 & 0 & 0 & 0 & 0 & 0 & 0 \\
\hline Mahajanga & Majunga & urb 1st cat & 2 & 1 & 3 & 1 & 0 & 1 & 2 & 10 \\
\hline Ambatondrazaka & Tamatave & urb 2nd cat & 1 & 0 & 0 & 0 & 0 & 0 & 0 & 1 \\
\hline \multicolumn{3}{|l|}{ TOTAL } & 23 & 2 & 18 & 3 & 1 & 2 & 3 & 52 \\
\hline
\end{tabular}

List of abbreviations:

Cat - Municipality's category (rur = rural; $u r b=$ urban $)$

CS - Chief of staff

FAM - Financial and administrative manager

CG - Management system controller

PA - Public accountant

Counc - Councillor 


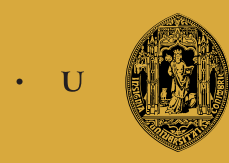

C - 